University of Tampere

School of Health Sciences

Female genital mutilation/cutting among women of Somali and Kurdish origin in Finland 
University of Tampere

School of Health Sciences

KOUKKULA MIMMI: Female genital mutilation/cutting among women of Somali and Kurdish origin in Finland

Master's Thesis, 39 pages

Supervisors: Ilmo Keskimäki, University of Tampere, National Institute for Health and Welfare Reija Klemetti, National Institute for Health and Welfare

Public Health

May 2015

\section{ABSTRACT}

The tradition of female genital mutilation/cutting (FGM/C), known to be practiced for example in Africa, Asia and the Middle East, has spread in Europe due to immigration. It has been estimated that half a million girls and women in Europe have been subjected to FGM/C. The procedure has several negative health impacts, including infections, bleeding and childbirth complications. The exact prevalence of $\mathrm{FGM} / \mathrm{C}$ and its health effects in Finland are unknown. This study explores the prevalence of FGM/C, the sociodemographic characteristics associated with it, and its health effects among women of Somali and Kurdish origin in Finland.

Data were obtained from the Migrant Health and Wellbeing Study carried out in 2010-2012, which was an interview survey with respondents representing the main migrant ethnic groups in Finland. This study uses data from interviews with Somali $(\mathrm{N}=165)$ and Kurdish $(\mathrm{N}=224)$ women. The participation rate was $37 \%$ for the women of Somali and $54 \%$ for the women of Kurdish origin.

The prevalence of FGM/C was $69 \%$ among the women of Somali and $32 \%$ among the women of Kurdish origin. Having no education and older age were significantly associated with $\mathrm{FGM} / \mathrm{C}$, as was marriage amongst women of Somali origin, and practice of Islam amongst women of Kurdish origin. Reporting good self-perceived health was more common among women without FGM/C. Outpatient visits to medical doctors were less common among women of Somali origin with $\mathrm{FGM} / \mathrm{C}$, compared to women without FGM/C. One fifth of both women of Somali and Kurdish origin with FGM/C reported reproductive problems because of $\mathrm{FGM} / \mathrm{C}$.

$\mathrm{FGM} / \mathrm{C}$ is more common among migrant women living in Finland than previously estimated, particularly among women of Kurdish origin. Actions against FGM/C are needed and the negative impacts of FGM/C need to be addressed in health services for immigrant women.

Keywords: FGM/C, female genital mutilation, female genital cutting, female circumcision, migrant women 


\section{Table of Contents}

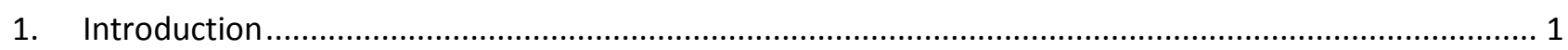

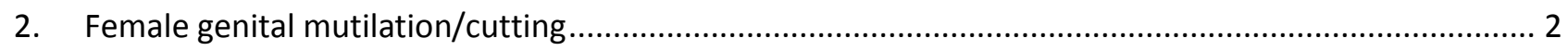

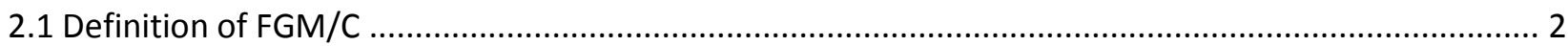

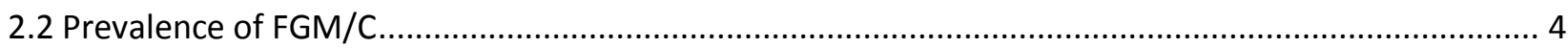

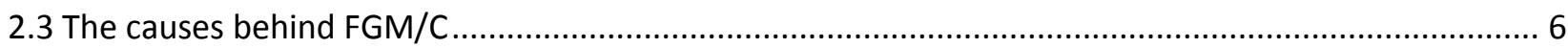

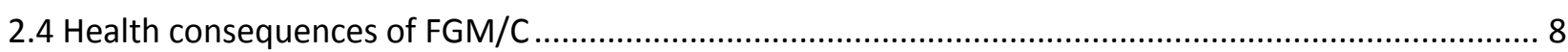

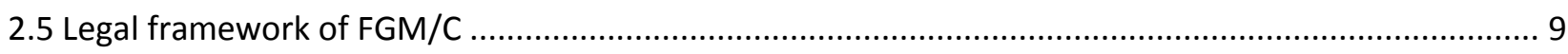

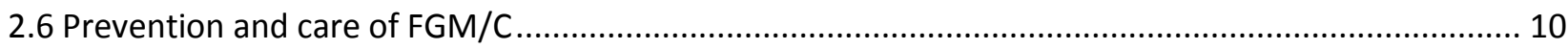

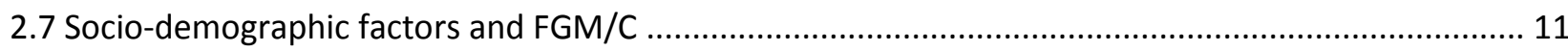

3. Ethnic minorities and FGM/C in Finland ............................................................................................ 12

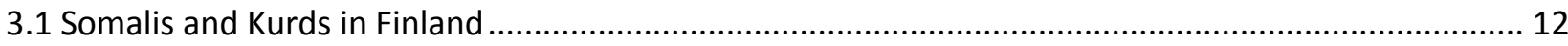

3.2 Socio-demographic factors and health among Somali and Kurdish immigrants .............................. 12

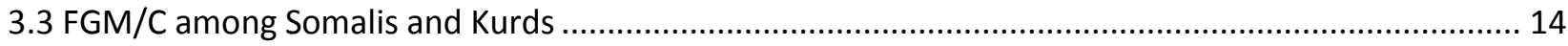

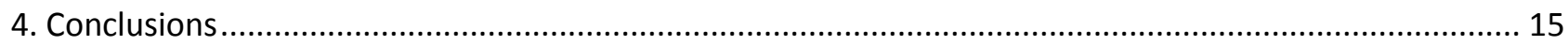

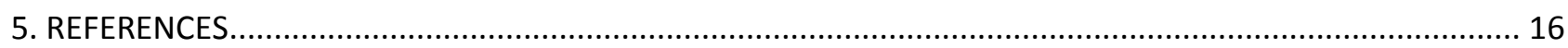

6. Article 
Abbrevations

EIGE European Institute for Gender Equality

WHO World Health Organization

FGM/C Female genital mutilation/cutting

STM Sosiaali-ja terveysministeriö, Ministry of Social Affairs and Health

THL Terveyden ja hyvinvoinnin laitos, National Institute for Health and Welfare

Maamu Maahanmuuttajien terveys- ja hyvinvointitutkimus, Migrant Health and Wellbeing Study 


\section{Introduction}

Female genital mutilation/cutting (FGM/C) includes all procedures that are performed for non-medical reasons involving partial or total removal of the external female genitalia, or other injury to the female genital organs (WHO 2014, UNICEF 2013). More than 125 million girls and women live with a genital mutilation/cutting in the world today and three million girls are at risk of being subjected to the practice every year (WHO 2014). Most of the girls who have been subjected to the practice are living in Africa and in some parts of Asia and Middle East but the tradition has risen to the global awareness because of the people who are cherishing the tradition have arrived as refugees or migrants to Europe or North America. FGM/C has been internationally recognized as a violation of human rights. The age-old tradition also reflects inequality between the sexes and discrimination against women. FGM/C violates children's rights and individuals' right to health, security and physical sanctity. (WHO 2014; UNICEF 2013.)

Approximately half a million girls and women in Europe have been subjected to FGM/C (European Institute for Gender Equality (EIGE) 2013). The research on FGM/C, its' health consequences and care requirements are scarce and concentrated on African countries (Andro, Cambois, \& Lesclingand 2014). Only 8 out of 28 EU member states have studies of FGM/C prevalence, $10 \mathrm{EU}$ member states have specific criminal law provision on $\mathrm{FGM} / \mathrm{C}$ and $7 \mathrm{EU}$ member states have information about $\mathrm{FGM} / \mathrm{C}$ contained in hospital/medical records (EIGE 2014). Among the professionals who are facing immigrants in Europe the lack of knowledge of FGM/C's negative effects on health has come to the fore in many researches (Andro et al. 2014).

In Finland the Ministry of Social Affairs and Health has published a specific action plan on the prevention of FGM/C for the years 2012-2016 (STM 2012). In the action plan it has been stated that there is very little research on FGM/C in Finland. Also in the report of the European Institute for Gender Equality (EIGE 2013) it is stated that in Finland there is lack of study of the number of women with FGM/C. Finnish research has focused mainly on Somali population; the few studies have been qualitative and have not attempted to identify the FGM/C prevalence in the country (EIGE 2013; Mölsä 2004; Tiilikainen 2003). For targeting preventive measures in the right way, it is important to produce and monitor the latest national and international research. In addition, the research data is needed for the basis of training and other materials. Universities are encouraged to guide students to make theses and studies on FGM/C and related themes. (STM 2012.)

In Finland, the National Institute for Health and Welfare (THL) has collected data on health, well-being, use of services and living conditions of working-age immigrants with Russian, Somali and Kurdish origin (Castaneda, Rask, Koponen, Mölsä \& Koskinen 2012). As part of this Migrant Health and Wellbeing Study 
(Maamu) the situation of FGM/C among the participants was asked. Data for this thesis is obtained from Maamu-study.

The purpose of this study is to explore the prevalence of FGM/C, socio-demographic characteristics associated with it, experienced health effects and outpatient visits to medical doctor among women with Somali and Kurdish origin in Finland. The study design is a descriptive cross-sectional study. In the literature review, the prevalence and causes of FGM/C as well as negative health effects and prevention of FGM/C are examined.

\section{Female genital mutilation/cutting}

\subsection{Definition of FGM/C}

Female genital mutilation/cutting has been defined by the World Health Organization (WHO) as "all procedures involving partial or total removal of the external female genitalia or other injury to the female genital organs for non-medical reasons" (WHO 2008). There are different terms used for the procedure. The word "mutilation" has been used to emphasize the human rights violation of the act, to support the political activity against FGM/C and to distinguish it from the male circumcision. At the end of the 1990's, the more culturally sensitive word "cutting" became common, expressing the cultural background of the procedure and that way supporting the preventive work. The combination "female genital mutilation/cutting" has been taken into use underscoring the non-judgemental approach with practising communities but not forgetting the criminal aspect of the tradition in many countries. (STM 2012; UNFPAUNICEF 2012.)

FGM/C is an age-old tradition where genitals are cut, incised or harmed for non-medical reasons. Usually, $\mathrm{FGM} / \mathrm{C}$ is performed on young girls. Typical age is between four and fourteen, but FGM/C occurs also among infants. Adult women can also be cut before marriage or after delivery. (UNICEF 2013; WHO 2014.)

FGM/C is often carried out by a traditional circumciser without anaesthesia or analgesia with non-sterile instruments in unhygienic conditions. (UNICEF 2013; WHO 2014; Balogun, Hirayama, Wariki, Koyanagi \& Mori 2013.) However, the traditional habits live and change and nowadays a number of FGM/C rituals have 
shifted to more individual ceremonies and non-sterile knives have been replaced with more hygienic razor blades (Kaplan, Cham, Njie, Seixas, Blanco \& Utzet 2013a). There has also been a shift from traditional cutters to healthcare professionals motivated by more safety and less painful procedure on the part of the parents. In the study of Shaeer \& Shaeer (2013) in the Middle East as many as 55\% ( $N=313$ ) of the FGM/C cases were performed by doctors and $10 \%$ by nurses. According to WHO (2014) more than $18 \%$ of all FGM/C is performed in official health care services and the trend towards medicalization of $\mathrm{FGM} / \mathrm{C}$ seems to be growing. This can lead to a false idea of FGM/C being a secure measure and therefore the procedure to become even more common. Medical personnel could though use this shift in the tradition as a possibility to educate the families about the risks of the procedure. (Shaeer \& Shaeer 2013.)

WHO (2008) classifies female genital mutilation/cutting into four main types.

Complete typology with sub-divisions:

Type I - Partial or total removal of the clitoris and/or the prepuce (clitoridectomy).

Type la, removal of the clitoral hood or prepuce only.

Type Ib, removal of the clitoris with the prepuce.

Type II - Partial or total removal of the clitoris and the labia minora, with or without excision of the labia majora (excision).

Type lla, removal of the labia minora only.

Type Ilb, partial or total removal of the clitoris and the labia minora.

Type IIc, partial or total removal of the clitoris, the labia minora and the labia majora.

Type III - Narrowing of the vaginal orifice with creation of a covering seal by cutting and appositioning the labia minora and/or the labia majora, with or without excision of the clitoris (infibulation).

Type Illa, removal and apposition of the labia minora.

Type IIIb, removal and apposition of the labia majora.

Type IV - All other harmful procedures to the female genitalia for non-medical purposes, for example: pricking, piercing, incising, scraping and cauterization. (WHO 2008.)According to UNICEF (2013) type IV can also be called "symbolic circumcision" and it has been suggested to use it instead of more radical types of circumcision. 
This typology gives a general impression of the procedure, but in practise, there are various types of cutting and often even the circumcised women themselves do not know the type they have been performed on. (UNICEF 2013.) There are also special terms for FGM/C in the cultures practising the tradition. In Muslim societies for example word Sunna is often understood as pricking the clitoral hood or other small operations. Still Sunna can refer to a variety of operations ranging from pouring a few drops of blood to the partial or total excision of the clitoris and total suturing of the vulva just as in normal infibulations. (World Bank \& UNFPA 2004.)

\subsection{Prevalence of FGM/C}

There are more than 125 million girls and women living with $\mathrm{FGM} / \mathrm{C}$ in the world today and 3 million girls are at risk of undergoing the practice every year (WHO 2014). FGM/C is reported all over the world but the tradition is most common in the western, eastern, and north-eastern regions of Africa where approximately 100 million girls and women live with FGM/C (Figure 1.). The high prevalence zone of FGM/C is distributed more or less contiguously from the Horn of Africa in the east to Senegal in the west. According to UNICEF (2013), these areas of high prevalence correspond to the sites of ancient empires, such as ancient Nubia, Kush or Meroa Empire in West Africa. Nearly half of the circumcised girls and women live in two countries; Egypt and Ethiopia. FGM/C prevalence is also high in some countries in Asia and the Middle East (ClarenceSmith 2008). In addition, FGM/C is common all over the world among the migrants from these areas. (WHO 2014; UNICEF 2013.)

There are only a few studies on FGM/C in Finland (Mölsä 2004) and those mainly concentrate on the Somali origin women and their experiences or on the care of the women with FGM/C. There are no precise numbers of the FGM/C cases in Finland. 


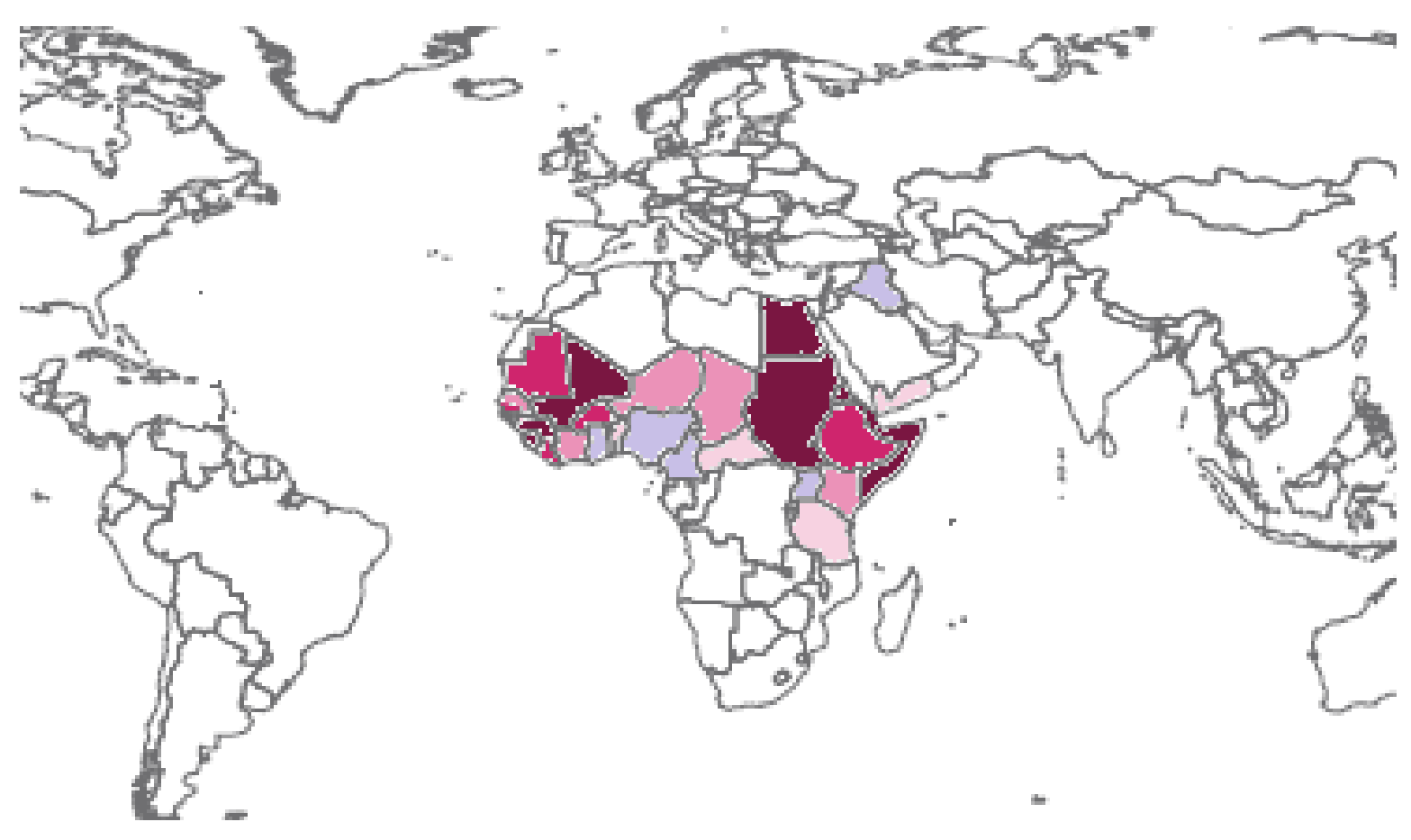

Figure 1. Prevalence of FGM/C.

Empty map's origin: http://digital-vector-maps.com/WORLD/WM-1979-Free-Vector-World-Maps.htm

over Somalia 98\%, Guinea 96\%, Djibouti 93\%, Egypt 91\%, Eritrea 89\%, Mali 89\%, Sierra Leone 88\%, $80 \% \quad$ Sudan $88 \%$

51 - 80\% Gambia 76\%, Burkina Faso 76\%, Ethiopia 74\%, Mauritania 69\%, Liberia 66\%

$26-50 \%$ Guinea-Bissau 50\%, Chad 44\%, Ivory Coast 38\%, Kenya 27\%, Nigeria 27\%, Senegal 26\%

10 - 25\% Central African Republic 24\%,Yemen 23\%, United Republic of Tanzania 15\%, Benin 13\% under

$10 \%$

Iraq $8 \%$, Ghana 4\%, Togo 4\%, Niger 2\%,Cameroon 1\%, Uganda $1 \%$

Also practised in Indonesia, Malaysia, in the Muslim dominated southern areas of Thailand, in the Kurdish areas of Iran, Israel, Jordania, Oman, Columbia, Peru, Democratic Republic of Kongo, Sri Lanka and in small areas of Europe and North America, but nationally representative estimates are not available. The tradition is also practised by a Muslim group called Dauri Bohra, located in the area of India and Pakistan.

(UNICEF 2013; WHO 2008.)

As a consequence of the international migration, the disadvantages of the FGM/C tradition have started to increase also in Europe, North America, Australia and New Zealand. Exact numbers of girls and women with FGM/C are not available from most of the destination countries of immigrants and the numbers are often based on estimates. There are approximately half a million circumcised girls and women in Europe. (WHO 2010; WHO 2014; UNICEF 2013.) The European Institute for Gender Equality (2013) has listed the studies concerning the number of $\mathrm{FGM} / \mathrm{C}$ victims in the European Union. According to their statistics there are 
approximately 66000 women with FGM/C in the UK, 61000 in France, 35000 in Italy and 19000 in Germany (EIGE 2013).

The risk of $F G M / C$ is still imminent after immigration to Europe (EIGE 2013). There is no evidence that FGM/C would be practised within the area of the European Union but still a large group of daughters of immigrants who are subjected to FGM/C while travelling outside the $\mathrm{EU}$ in the area. It is estimated that 180000 girls are at risk of FGM/C in Europe. (EIGE 2013.) Isman, Ekéus and Berggren (2013) have estimated that in Scandinavia there are 100000 immigrants from the countries where FGM/C is a tradition. Elgaali, Strevens and Mardh (2005) showed in their small quantitative study that $19 \%$ ( $N=220$ ) of the daughters of the African immigrants in Scandinavia had been circumcised whilst living in Scandinavia.

\subsection{The causes behind FGM/C}

FGM/C is deeply rooted into cultural and social factors. It is predominantly an African tradition although its historical origins are not known so precisely. The tradition is assumed to originate back to the areas of the ancient Egypt and Sudan and it has been practised before the Christianity and Islam well over 2000 years ago. (STM 2012; UNICEF 2013.)

The causes behind FGM/C vary in different regions according to the prevailing culture. According to Yasin, Al-Tawil, Shabila and Al-Hadithi (2013) an important factor for the continuation of FGM/C is the inheritance of tradition and customs from mothers to their daughters. In the families where FGM/C is practised, it is often seen as a necessary part of raising a girl (Balogun et al. 2013). In particular cultures, FGM/C is an important rite of passage from childhood to adulthood and it can be seen as a symbol of sexual maturity. $\mathrm{FGM} / \mathrm{C}$ can be seen as a symbol of female identity. It is thought that FGM/C changes a girl to a woman when the masculine parts of the body are removed. FGM/C guarantees social acceptance to a girl in her own society when she gains genitals that are comprehended normal in her community. (Ahanonu \& Victor 2014; STM 2012.) FGM/C can be thought as an esthetical issue, when the circumcised girl is seen as beautiful in her community (Hussein 2008). 
The tradition has a connection to getting ready for adulthood and marriage. Beliefs of decency, respectability and virginity before marriage are associated with the FGM/C tradition (Talle 2008; Hussein 2008; Norman, Hemmings, Hussein \& Otoo-Oyortey 2009). In some societies, the validity of marriage verified by $\mathrm{FGM} / \mathrm{C}$ is the requirement of getting married. $\mathrm{FGM} / \mathrm{C}$ is presumed to diminish over sexuality and hyperactivity in the sexual practice of women and to increase the husband's sexual pleasure but also to protect the girl form raping (Balogun et al. 2013; Talle 2008; Norman et al. 2009; Yirga, Kassa, Gebremichael \& Aro 2012). In some communities it is common to believe that FGM/C improves fertility and child survival. FGM/C is also seen as a purifying act where ritually unclean genital organs are removed and therefore hygiene is improved and infections are prevented. (Balogun et al. 2013; Isman et al. 2013; Ahanonu \& Victor 2014.)

Among immigrants, the cultural continuity is important and FGM/C can be used to maintain the cultural identity. With the help of signs associated with body, the cultural and ethnic character of the community can be defined and that way make the linkage to one's own cultural background stronger. (Norman et al. 2009; STM 2012; THL 2014.)

Even though no religion requires $\mathrm{FGM} / \mathrm{C}$, the tradition is often perceived to be part of religious norms. $\mathrm{FGM} / \mathrm{C}$ is mentioned in Islamic spoken tradition though the teachings in Koran do not include it. Religious leaders have recently emphasized that $\mathrm{FGM} / \mathrm{C}$ is against Islam, which has supported the diminishing of the most radical types of FGM/C. (Balogun et. al .2013; STM 2012.)

FGM/C has financial consequences. The tradition is often implemented by traditional circumcisers or local healers, who also have other important roles in communities as taking care of deliveries. Stopping the tradition would take their income, which is usually relatively high in the community. Therefore the circumcisers often act as obstacles on a preventive work of FGM/C. (THL 2014.) In some countries, midwives perform FGM/C to supplement their low salaries (Berggren, Salam, Bergström, Johansson \& Edberg 2004). Also the families might have a financial motivation to circumcise their daughters because the prize of a girl with $\mathrm{FGM} / \mathrm{C}$ is higher than a girl's without $\mathrm{FGM} / \mathrm{C}$ when families are agreeing on marriage. (THL 2014.) 


\subsection{Health consequences of FGM/C}

FGM/C is not found to have any health benefits. On the contrary, removing and damaging of healthy tissue interferes with the normal physiological functioning of a girl's and woman's body. The degree of cutting and the circumstances, under which the procedure is performed, affect the incidence of negative health impacts. (Andro et. al. 2014; WHO 2011.) According to Berg's, Denison's and Fretheim's (2010) systematic review the health consequences are similar to FGM/C types I, II and III, but the wider the degree of cutting is, the more severe and prevalent the harm is. It is important to realise that girls and women with FGM/C can consider their health problems caused by FGM/C normal because almost every girl and woman in their community have the same discomfort. Thereafter the women with FGM/C often do not understand their ailments to be caused by FGM/C. (UNICEF 2013.)

The health consequences of FGM/C can be divided into immediate and long-term effects (WHO 2014). The short-term health consequences of FGM/C are severe pain and shock caused by pain. Excessive or prolonged bleeding can lead to anaemia, decrease in blood pressure, shock and even to death. Various bacterial and viral infections are possible in the wound, urinary tract or pelvic area and can spread up into a sepsis. Tetanus, Hepatitis B, C- and HIV-infections are spreading via FGM/C. (Andro et. al. 2014; EIGE 2013; WHO 2014.) Studies indicate that the more tissue is cut, the higher is the risk for infection (END FGM 2008). Damage in the nearby tissue and organs, such as damage to the urethra, are possible. In addition, bone fractures and limb dislocations due to holding appear. As immediate psychological problems occur fear, shock, stress and nightmares. (Andro et al. 2014; EIGE 2013; THL 2014; WHO 2014).

The long-term health risks of FGM/C are repeated urinary tract infections and difficulty in passing urine and faeces, painful menstruation and sexual intercourse (WHO 2014). An ail scarring can result in cysts, abscesses, nerve tumours, tissue inflexibility, genital ulcers, excessive keloid scar tissue formation, fistulas and accumulation of menstrual blood in the vagina. In the areas of high HIV prevalence, HI-virus can spread from unsterile instruments used for FGM/C and FGM/C in itself increases susceptibility to HIV infection and other sexually transmitted diseases. Memories of the operation as well as the changes in genital anatomy can lead to reduced quality of sex life by increasing the fear of intercourse, painful intercourse and problems getting an orgasm. (WHO 2008; WHO 2014; EIGE 2013; Andro et al. 2014.) The male partners of women with $\mathrm{FGM} / \mathrm{C}$ have also reported of the physical and psychosexual problems like experiencing pain and complications during intercourse with woman with FGM/C (WHO 2011; Varol, Fraser, Ng, Jaldesa, \& 
Hall 2014). Infertility is more common in women with FGM/C. In an Egyptian study of women with and without FGM/C ( $N=400)$ infertility was almost threefold $(\mathrm{OR}=2.9)$ among the women with $\mathrm{FGM} / \mathrm{C}$ (Kasim, Shaaban, El Sadak \& Hassan 2012). Long term psychological consequences are post-traumatic stress, nightmares and depression. (Kizilhan 2011; WHO 2014; EIGE 2013.) Also ongoing resentment towards family members responsible for the procedure has been reported (Norman et al. 2009).

FGM/C causes an increased risk of obstetric complications and the risk of birth complication increases with the degree of cutting (WHO 2011). Monitoring of the fetus and the progress of delivery may be more difficult with women with FGM/C (Widmark, Levál, Tishelman \& Ahlberg 2010). Fear of giving birth can complicate the delivery. The most common obstetric complications of FGM/C are prolonged labour and/or obstruction, perineal tears and postpartum haemorrhage. Also episiotomies and unnecessary caesarean sections are more common among parturients with FGM/C. Chronic infections can be transmitted to the infant and may cause the death of the new-born. (WHO 2014; Balogun et al. 2013; Thierfelder, Tanner \& Bodiang 2005.) WHO's (2006) extensive survey investigated 28393 women in African countries and estimated that women with $\mathrm{FGM} / \mathrm{C}$ were notably more likely to have unfavourable obstetric outcomes, as caesarean section, infant resuscitation and perinatal death, than those without FGM/C. According to the survey, approximately 1-2 children per 100 births die because of the mother's FGM/C. (WHO 2006.) The number is not as big if the delivery is taking place in more advanced circumstances. Another study from Gambia ( $N=588$ ) showed that the new-borns of women with $F G M / C$ are four times more likely to have health complications than the new-borns of women without FGM/C (Kaplan, Forbes, Bonhoure, Utzet, Martin, Manneh \& Ceesay 2013b). During childbirth the flashbacks of the FGM/C-situation are possible, birth can be experienced as a new form of abuse and women with FGM/C have reluctance to give birth again. (Lyberg, Viken, Haruna \& Severinsson 2012; WHO 2014; Balogun et.al. 2013.)

\subsection{Legal framework of FGM/C}

Finland has ratified various international conventions condemning $F G M / C$, including the Universal Declaration of Human Rights (UDHR), the Convention on the Elimination of all Forms of Discrimination against Women (CEDAW), the Convention against Torture and Other Cruel, Inhuman or Degrading Treatment or Punishment (CAT), the Convention on the Rights of the Child (CRC), the Convention for the Protection of Human Rights and Fundamental Freedoms (ECHR), and the Charter of Fundamental Rights of 
the European Union (2010/C 83/02). Finland has signed the Council of Europe Convention on Preventing and Combating Violence against Women and Domestic Violence (CETS No. 210). (EIGE 2014.) In Finland FGM/C is treated as a crime and even if it is committed outside the country it is punishable (Criminal law 1889/39) (Ministry of Justice 1889). Also the Child Welfare Act can be used in child protection cases concerning FGM/C (STM 2007).

\subsection{Prevention and care of FGM/C}

According to WHO (2014) there has been intensive work to counteract FGM/C since 1997. The prevalence of FGM/C has been declining for the last decades in almost all countries practising the tradition but there are enormous variations between countries and communities. In some communities, the practice has been more than halved lately but in some countries there seems to be no change at all. (Johansen, Diop, Laverack \& Leye 2013.) In Somaliland for example civil society organizations have been involved in the preventive work by creating awareness and providing alternative skills to circumcisers but the progress has been slow (Gulaid 2008). In a study by Mitike \& Deressa (2009) it was found out that among Somali refugees the participation of the parents in anti-FGM interventions was statistically associated with lower practice of FGM/C and plans of FGM/C. According to Yasin and colleagues (2013) one key factor in the prevention of $\mathrm{FGM} / \mathrm{C}$ is the education of women.

In Europe there has been a lot of preventive work done. Preventive work is responsibility of all authorities that face immigrants in their work and information about the tradition should be included in the basic education of these profession groups (Johansson 2008). Preventive work should consist of work within communities promoting change in the social and cultural attitudes, creating guidelines and protocols for professionals and training them, and influencing public policy to constitute laws against FGM/C. ( EIGE 2013; WHO 2014; Cappon, L’Ecluse, Clays, Tency \& Leye 2015; Dawson, Turkmani, Fray, Nanayakkara, Varol \& Homer 2015.) For the prevention of FGM/C more extensive international involvement is still needed for example in the form of monitoring bodies and resolutions. (WHO 2014; EIGE 2013.)

The care that health care sector can provide for the women living with FGM/C usually includes surgery to open the circumcision (deinfibulation) (WHO 2014). The perineum is usually cut (episiotomy) during birth to widen the vaginal opening so the baby can be born. Cysts and other abnormalities may be removed and 
infections treated properly. Women with $\mathrm{FGM} / \mathrm{C}$ and their partners should be offered counselling on the harmful effects of FGM/C to ease their decision making about the care they might receive. (Balogun et al. 2013.)

The subject of $F G M / C$ is very sensitive and women with $F G M / C$ face many barriers utilizing health care services (Ameresekere, Borg, Frederick, Vragovic, Saia \& Raj, 2011; Norman et al. 2009). A British study (Norman et al. 2009) found out that the barriers consist of poor communication skills and language problems of health providers which can lead women feeling different or abnormal, health providers not understanding the special needs of women with FGM/C and incompetent care of childbirth in the case of $\mathrm{FGM} / \mathrm{C}$.

\subsection{Socio-demographic factors and FGM/C}

Previous studies have showed that certain socio-demographic factors are associated with FGM/C. In Yasin's (2013) and colleagues' study found out that the most significant factors associated with FGM/C were the education of girl's father and the employment status of girl's mother. Saleem (2013) and his colleagues showed that children of uneducated mothers were eight times as likely to have had FGM/C compared with children of mothers with over nine years education. Refaat, Farag and Ramadan (2009) showed that educated women's daughters are less likely to undergo FGM/C.

The marital status of woman has been associated with FGM/C (Saleem, Othman, Fattah, Hazim and Adnan 2013): FGM/C was more common among married than unmarried women. Among women aged 17 years and younger, $34 \%$ of those who were married had been circumcised versus $17 \%$ of those who were not married. (Saleem et al. 2013.) FGM/C has also been shown to be more likely carried out in rural than in urban settings, since the former are more likely to be kinship-based communities with limited cultural diversity (Refaat, Farag \& Ramadan 2009; UNICEF 2013). 


\section{Ethnic minorities and FGM/C in Finland}

In Finland 208000 inhabitants had a foreign citizenship in 2013. Somalis comprised the fourth biggest group with 7500 people and Iraqis the seventh biggest group with 6400 people. (Official Statistics of Finland 2015.) In Europe information on the health of migrants is scarce which detract the monitoring and advancing the health of migrants (Rechel, Mladovsky \& Deville 2012).

\subsection{Somalis and Kurds in Finland}

Somalis were the first large group of refugees arriving in Finland as spontaneous asylum seekers. In the late 1980 's, the first Somali asylum seekers arrived in Finland and in the 1990's the numbers increased.

(Tiilikainen 2003, 50.) Since the 1990's, the number of Somalis in Finland has increased and nowadays Somalis form the largest refugee, Muslim and African-backed group of immigrants living in Finland. In 2013 15789 Somali speaking people lived in Finland. (Official Statistics of Finland 2015.)

Kurds live in the region of southwest Asia, known as Kurdistan, consisting of Turkey, Iran, Iraq, Armenia and Syria. They are largely Sunni Muslim people and they have their own language and culture. (Encyclopaedia Britannica 2014.) Most of the Kurds in Finland are part of the larger Kurdish exile which happened in 19902000. Mainly, the Kurds in Finland come from Iraq, Iran and Turkey. (Toivanen 2013; Wahlbeck 2005.) In 2013 there were 9000 people with Iraqi or Iranian citizenship living in Finland (Official Statistics of Finland 2015).

\subsection{Socio-demographic factors and health among Somali and Kurdish immigrants}

The phenomenon of immigration is still new in Finland and only a few studies have focused on migrant health in the country (Apter, Eskola, Säävälä \& Kettu 2009). From other European countries it is known that 
a notable share of migrants have problems with health and wellbeing in their new home countries. The health of immigrants is shown to be weaker than the main populations (Kumar, Grøtvedt, Haakon, Meyer, Søgaard \& Strand 2008; Smith, Chaturvedi, Harding, Nazroo \& Williams 2000). There are also big differences in health and wellbeing inside the immigrant populations depending on the level of education and income (Koskinen, Castaneda, Rask, Koponen \& Mölsä 2012). Ethnic minorities and migrants utilize the health care services less in relation to their needs and differently than the original population (Malin 2011; Keygnaert, Guieu, Ooms, Vettenburg, Temmerman \& Roelens 2014; Rask, Castaneda, Koponen, Sainio, Stenholm, Suvisaari, Juntunen, Halla, Härkänen \& Koskinen 2015; Rechel et al. 2012). According to Keygnaert et al. (2014) migrants also use sexual and reproductive health services far less than EU citizens. The financial and language problems as well as the complexity of the system diminish the usage of services. (Keygnaert et al. 2014; Degni, Koivusilta \& Ojanlatva 2006a.)

In Finland, the age structure of immigrants is younger than the main population's and immigrants do not have higher education as often as the main population. The level of unemployment is higher among immigrants and the income lower than the main population's. (Pohjanpää, Paananen \& Nieminen 2003.) The fertility rate of migrants is higher than the main populations. Women of Somali and Iraqi origin have on average more than four children. (Apter et al. 2009.) Immigrants in Finland also use less health services than the main population except a group of female immigrants, aged 15-29 years, who have more outpatient visits to hospitals because of pregnancy and birth than the main population (Gissler, Malin \& Matveinen 2006).

According to Degni and colleagues (2006a) health care services including those of family planning have been scarce in the past in Somalia, so the women of Somali origin do not have a routine on using those. In a Finnish register based study ( $\mathrm{N}=6532$ ) on maternal care and birth outcomes among ethnic minority women, the women of African and Somali origin had most health problems resulting in the highest perinatal mortality rates. Somali origin singleton new-borns had two-fold perinatal mortality compared with the babies of the overall population. Women with Somali origin had a significant risk of low birth weight and risk of small for gestational age new-borns. (Malin \& Gissler 2009.) 


\subsection{FGM/C among Somalis and Kurds}

In Somalia FGM/C is very common. Approximately 6.5 million girls and women have been circumcised, meaning that $98 \%$ of the female population lives with FGM/C (UNICEF 2013). Nearly $90 \%$ of FGM/C's in Somalia are infibulations (World Bank \& UNFPA 2004). Already in 2004 Mölsä found out that migrants of Somali origin in Finland have started to prefer the less severe sunna form of FGM/C over the more extensive forms. Also according to a recent study by Gele, Bo \& Sundby (2013) there has been a change to milder forms of FGM/C in Somalia. They found out that $16 \%$ of women in their study had FGM/C of sunnastyle.

In Somalia FGM/C has been valued because it is an important rite of passage to womanhood and it strengthens the bond with the girl's father's lineage. Nowadays FGM/C is considered to protect girls from premarital sex and pregnancies and it is a prerequisite for marriage. (Tiilikainen 2003, 269; Fried, Warsame, Berggren, Isman \& Johansson 2013). FGM/C is mainly performed by a traditional circumciser to girls aged five to eight (World Bank \& UNFPA 2004). A World Banks' report (2004) claimed that $90 \%$ of Somali women supported the continuation of FGM/C. Somalis living in exile have begun to question the need for FGM/C and recent studies have shown that more radical forms of FGM/C like infibulation are in particular reduced but partly because there has been a shift to favour the smaller types (Sunna) as it is thought to be a religious requirement and less harmful than other forms of FGM/C (Fried et al. 2013; Gele et al. 2013). Often when living in exile Somali parents' ideals of upbringing a child can change from the prevailing views in the home country like questioning the tradition of $\mathrm{FGM} / \mathrm{C}$ but the situation may change after returning to the home country. (Degni, Pöntinen \& Mölsä 2006b; Tiilikainen 2003, 270.)

FGM/C is habitual in Iranian and Iraqi Kurdish regions, but in neighbouring Turkey it is not as common WADI 2010). According to several studies, the prevalence of FGM/C in Iraqi Kurdistan is at least $40 \%$ but in some rural areas the share of females with FGM/C can be as high as 70\% (Human Rights Watch 2011; WADI 2010; Yasin et al. 2013; Shabila, Saleh \& Jawad 2014; Shaeer \& Shaeer 2013). Yasin (2013) with his colleagues has studied ( $N=1987$ ) Kurdish women in Iraq and they found out that $70.3 \%$ of them were circumcised and $99.6 \%$ of the FGM/C's were the type I mutilations. There is evidence that the most common age of FGM/C among Kurds is between four and seven years (Yasin et al. 2013). In Saleem's (2013) and his study group's survey in Iraqi Kurdistan area ( $N=1508$ ) the FGM/C prevalence was $23 \%$ and $54 \%$ of $\mathrm{FGM} / \mathrm{C}$ cases it was performed by traditional birth attendants or midwives. 


\section{Conclusions}

According to the findings of this literature review, studies on FGM/C, experienced health consequences of FGM/C and care requirements are scarce and concentrate mainly on African countries. In the area of EU there are some studies of FGM/C prevalence but in Finland there are no precise estimates for the prevalence or the health impacts of $\mathrm{FGM} / \mathrm{C}$ among immigrant women living in the country. Research on FGM/C in Finland has focused mainly on Somali population; the few studies have been qualitative and have not attempted to identify the FGM/C prevalence.

Further studies with larger sample and with birth register data are needed. For targeting preventive measures in the right way, it is important to produce information on the prevalence and health impacts of FGM/C. The research on FGM/C is also needed for educating health care professionals and for the basis of training and other materials. 


\section{REFERENCES}

Ahanonu, E.L., Victor, O. 2014. Mother's perceptions of female genital mutilation. Health Education Research, 1-7.

Ameresekere, M., Borg, R., Frederik, J., Vragovic, O., Saia, K. \& Raj, A. 2011. Somali immigrant women's perceptions of cesarean delivery and patient-provider communication surrounding female circumcision and childbirth in the USA. International Journal of Gynecology and Obstetrics 115. 227-230.

Andro, A., Cambois, E. \& Lesclingand, M. 2014. Long-term consequences of Female Genital Mutilation in a European context: self perceived health of FGM women compared to non-FGM women. Social Science \& Medicine. 106: 177-84.

Apter, D., Eskola, M-S., Säävälä, M. \& Kettu, N. 2009. Maahanmuuttajien seksuaali- ja lisääntymisterveyden edistäminen. - Tarpeita, tietoa ja yhdenvertaisuutta - Toimintasuunnitelma. Helsinki: Väestöliitto.

Balogun, O., Hirayama, F., Wariki, W., Koyanagi, A. \& Mori, R. 2013. Interventions for improving outcomes for pregnant women who have experienced genital cutting (Review). The Cochrane Library, 2.

Berg, R., Denison, E. \& Fretheim, A. 2010. Psychological, social and sexual consequences of female genital mutilation/cutting (FGM/C): a systematic review of quantitative studies. Norwegian Knowledge Centre for the Health Services. Report $13-2010$. Oslo.

Berggren, V., Salam, G.A., Bergström, S., Johansson, E. \& Edberg, A-K. 2004. An explorative study of Sudanese midwives' motives, perceptions and experiences of re-infibulation after birth. Midwifery, 20, 4. 299-311.

Cappon, S., L'Ecluse, C., Clays, E., Tency, I., Leye, E. 2015. Female genital mutilation: Knowledge, attitude and practices of Flemish midwives. Midwifery 31, 29-35.

Clarence-Smith, W. G. 2008. Islam and Female Genital Cutting in Southeast Asia: The Weight of the Past. Finnish Journal of Ethnicity and Migration. 3(2).

Castaneda, A., Rask, S., Koponen, P., Mölsä, M. \& Koskinen, S. 2012. Migrant health and wellbeing. A study on persons of Russian, Somali and Kurdish origin in Finland. National Institute for Health and Welfare (THL). Report 61/2012. Helsinki 2012. (Report in Finnish with English summary)

Dawson, A., Turkmani, S., Fray, S., Nanayakkara, S., Varol, N. \& Homer, C. 2015. Evidence to inform education, training and supportive work environments for midwives involved in the care of women with female genital mutilation: A review of global experience. Midwery 31: 229-238. 
Degni, F., Koivusilta, L. \& Ojanlatva, A. 2006a. Attitudes towards and perceptions about contraceptive use among married refugee women of Somali descent living in Finland. The European Journal of Contraception and Reproductive Health Care, 11,3:190-196.

Degni, F., Pöntinen, S. \& Mölsä, M. 2006b. Somali Parents' Experiences of Bringing up Children in Finland: Exploring Social-Cultural Change within Migrant Households. Qualitative social research, 7, 3.

EIGE. European Institute for Gender Equality. 2013. Female genital mutilation in the European Union and Croatia. Report. European Union.

EIGE. European Institute for Gender Equality. 2014. Country Fact Sheet.

http://eige.europa.eu/content/female-genital-mutilation Accessed 28.3.2014

Elgaali, M., Strevens, H. \& Mårdh, PA. 2005. Female genital mutilation -- an exported medical hazard. The European Journal of Contraception and Reproductive Health Care. 10(2):93-7. Encyclopaedia Britannica. 2014. Kurd. http://global.britannica.com/EBchecked/topic/325191/Kurd Accessed 7.5.2014

END FGM. 2008. Ending Female Genital Mutilation. A strategy for the European Union institutions. Executive summary. http://www.endfgm.eu/content/assets/END FGM Final Strategy Summary.pdf Accessed 15.2.2015

Fried, S., Warsame, A.M., Berggren, V., Isman, E., Johansson, A. 2013. Outpatients' Perspectives on Problems and Needs Related to Female Genital Mutilation/Cutting: A Qualitative Study from Somaliland. Obstetrics and Gynecology International, 1-11.

Gele, A.A., Bo, B.P., Sundby, J. 2013. Have we made progress in Somalia after 30 years of interventions? Attitudes toward female circumcision among people in the Hargeisa district. BMC Research Notes, 6, 122.

Gissler, M., Malin, M. \& Matveinen, P. 2006. Maahanmuuttajat ja julkiset palvelut: Terveydenhuollon palvelut ja sosiaalihuollon laitospalvelut. Työpoliittinen tutkimus 296. Helsinki: Työministeriö.

Gulaid, U. J. 2008. The Challenge of Female Genital Mutilation in Somaliland. Projects Reports. Finnish Journal of Ethnicity and Migration. 3(2)

Human Rights Watch. 2011. Iraqi Kurdistan: Law Banning FGM a Positive Step. 2011.

http://www.refworld.org/docid/4e37aac92.html Accessed 7.4.2001 
Hussein, F.-H. M. 2008. Changing Attitudes towards FGM in Somali Community in London. Project Reports. Finnish Journal of Ethnicity and Migration. 3(2).

Isman, E., Ekéus, C. \& Berggren, V. 2013. Perceptions and experiences of female genital mutilation after immigration to Sweden: An explorative study. Sexual \& Reproductive Healthcare. 4, 93-98.

Johansen, E., Diop, N., Laverack, G. \& Leye, E. 2013. What Works and What Does Not: A Discussion of Popular Approaches for the Abandonment of Female Genital Mutilation. Obstetrics and Gynecology International. Article ID 348248. http://dx.doi.org/10.1155/2013/348248

Johansson, J. 2008. Methods for the Prevention of Female Genital Cutting in Finland. Finnish Journal of Ethnicity and Migration. 3(2).

Kaplan, A., Cham, B., Njie, L.A., Seixas, A., Blanco, S. \& Utzet, M. 2013a. Female Genital Mutilation/Cutting: The Secret World of Women as Seen by Men. Obstetrics and Gynaecology International. Article ID 643780. http://dx.doi.org/10.1155/2013/643780

Kaplan, A., Forbes, M., Bonhoure, I., Utzet, M., Martin, M., Manneh, M. \& Ceesay, H. 2013b. Female genital mutilation/cutting in The Gambia: long-term health consequences and complications during delivery and for the newborn. International Journal of Women's Health 2013:5. 323-331.

Kasim, K., Shaaban, S., El Sadak, A. \& Hassan, H. 2012. Impacts of Female Genital Mutilation on Women's Reproductive Health. Community Medicine \& Health Education. 2:3.

Keygnaert, I., Guieu, A., Ooms, G., Vettenburg, N., Temmerman, M., Roelens, K. 2014. Sexual and reproductive health of migrants: Does the EU care? Health Policy 2014:114(2-3):215-225.

Kizilhan, J. I. 2011. Impact of psychological disorders after female genital mutilation among Kurdish girls in Northern Iraq. Eur J Psychiat 25:92-100.

Koskinen, S., Castaneda, A.E., Rask, S., Koponen, P. \& Mölsä, M. 2012. In Castaneda, A., Rask, S., Koponen, P., Mölsä, M., Koskinen, S. (Ed.) Migrant health and wellbeing. A study on persons of Russian, Somali and Kurdish origin in Finland. Report 61/2012. Helsinki: National Institute for Health and Welfare (THL). (Report in Finnish with English summary)

Kumar, B.N., Grøtvedt, L., Haakon, E., Meyer,H., Søgaard, A. \& Strand, B.H. 2008. The Oslo Immigrant Health Profile. Rapport:7. Folkehelseinstituttet. 
Lyberg, A., Viken, B., Haruna, M. \& Severinsson. 2012. Diversity and challenges in the management of maternity care for migrant women. Journal of Nursing Management. 20; 287-295.

Malin, M. 2011. Maahanmuuttajien terveyteen ja hyvinvointiin vaikuttavat tekijät. Yhteiskuntapolitiikka 76 (2011) : 2 .

Malin, M. \& Gissler, M. 2009. Maternal care and birth outcomes among ethnic minority women in Finland. BMC Public Health. 2009, 9:84.

Ministry of Justice. 1889. Criminal law. 1889/39. www.finlex.fi Accessed 15.1.2015

Mitike, G. \& Deressa, W. 2009. Prevalence and associated factors of female genital mutilation among Somali refugees in eastern Ethiopia: a cross-sectional study. Research article. BMC Public Health. 9:264.

Mölsä, M. 2004. Ajat ovat muuttuneet. Selvitys tyttöjen ja naisten ympärileikkaukseen liittyvistä asenteista ja aikeista pääkaupunkiseudulla asuvien maahanmuuttajien keskuudessa. Helsinki: Ihmisoikeusliitto, 3, 4.

Norman, K., Hemmings, J., Hussein, E. \& Otoo-Oyortey, N. 2009. FGM is always with us. Experiences, perceptions and beliefs of women affected by female genital mutilation in London. Results from A PEER study. Options Consultancy Services and Foundation for Women's Health, Research and Development, London.

Official Statistics of Finland (OSF): Official Statistics of Finland [e-publication].

Helsinki: Advisory Board of OSF. http://www.stat.fi/meta/svt/index en.html Accessed 3.4.2015

Pohjanpää, K., Paananen, S. \& Nieminen, M. 2003. Maahanmuuttajien elinolot. Venäläisten, virolaisten, somalialaisten ja vietnamilaisten elämää Suomessa 2002. Elinolot: 1. Helsinki: Tilastokeskus.

Rask, S., Castaneda, A., Koponen, P., Sainio, P., Stenholm, S., Suvisaari, J., Juntunen, T., Halla, T., Härkänen, T. \& Koskinen, S. 2015. The association between mental health symptoms and mobility limitation among Russian, Somali and Kurdish migrants: a population based study. BMC Public Health, 15:275.

Rechel, B., Mladovsky, P., Deville, W. 2012. Monitoring migrant health in Europe: A narrative review of data collection practices. Health Policy 2012, 105(1):10-16.

Refaat, L., Farag, A. \& Ramadan, I. 2009. Socio-demographic characteristics of female genital mutilation and its relation to sexual function. AAMJ. 7, 2. 
Saleem, R., Othman, N., Fattah, F., Hazim, L. \& Adnan, B. 2013. Female Genital Mutilation in Iraqi Kurdistan: Description and Associated Factors. Women \& Health, 53:6. 537-551.

Shabila, N., Saleh, A. \& Jawad, R. 2014. Women's perspectives of female genital cutting: Q-methodology. BMC Women's Health. 14:11.

Shaeer, O. \& Shaeer, E. 2013. The Global Online Sexuality Survey: Public Perception of Female Genital Cutting among Internet Users in the Middle East. J Sex Med. 10:2904-2911.

Smith, G., Chaturvedi, N., Harding, S., Nazroo, J. \& Williams, R. 2000. Ethnic inequalities in health: A review of UK epidemiological evidence. Critical Public Health, 10,4:375-408.

STM. Ministry of Social Affairs and Health. 2007. Lastensuojelulaki 13.4.2007/417. www.finlex.fi Accessed 14.1.2014

STM. Ministry of Social Affairs and Health. 2012. Action Plan for the prevention of circumcision of girls and women 2012-2016 (FGM). Helsinki: Publications of the Ministry of Social Affairs and Health.

Talle, A. 2008. Precarious Identities: Somali Women in Exile. Finnish Journal of Ethnicity and Migration. 3(2).

Thierfelder, C., Tanner, M. \& Bodiang, C. 2005. Female genital mutilation in the context of migration: experience of African women with the Swiss health care system. European Journal of Public Health. 15,1: 86-90.

THL. 2014. Tyttöjen ja naisten ympärileikkausten (FGM) ehkäisy. http://www.thl.fi/fi Fl/web/kasvunkumppanit-fi/tyon/ehkaiseva/tyttojenymparileikkaus Accessed 14.1.2014

Tiilikainen, M. 2003. Arjen islam: somalinaisten elämää Suomessa. Tampere: Vastapaino

Toivanen, M. 2013. Language and negotiation of identities among young Kurds in Finland. Nordic Journal of Migration Research. 3, 27-35.

UNFPA-UNICEF. 2012. Joint Programme on Female Genital Mutilation/Cutting: Accelerating Change. Scaling up a comprehensive approach to abandonment in 15 African countries. Annual report. 
UNICEF. 2013. Female Genital Mutilation/Cutting: A statistical overview and exploration of the dynamics of change. United Nations Children's Fund, New York.

Varol, N., Fraser, I. S., Ng, C. H. M., Jaldesa, G. \& Hall, J. 2014. Female genital mutilation/cutting - towards abandonment of a harmful cultural practice. Review article. Journal of Obstetrics and Gynaecology, 54, 400-405.

WADI. 2010. FGM. Female genital mutilation in Iraqi-Kurdistan. An empirical study by WADI. Association for Crisis Assistance and Development Co-operation. Germany.

http://www.stopfgmkurdistan.org/study fgm iraqi kurdistan en.pdf Accessed 07.04.2014

Wahlbeck, Ö. 2005. Kurds in Finland. In Ember, M., Ember, C.R. \& Skoggard, I. (Ed.)In Encyclopedia of Diasporas. Immigrant and Refugee Cultures Around the World. Springer US. 1004-1010.

WHO. 2006. Female genital mutilation and obstetric outcome: WHO collaborative prospective study in six African countries. Lancet 367, 1835-41.

WHO. 2008. Eliminating female genital mutilation. An interagency statement - OHCHR, UNAIDS, UNDP, UNECA, UNESCO, UNFPA, UNHCR, UNICEF, UNIFEM, WHO.

WHO. 2010. Global strategy to stop health-care providers from performing female genital mutilation.

WHO. 2011. An update on WHO's work on female genital mutilation (FGM). Progress report.

WHO. 2014. Female genital mutilation. Fact sheet $\mathrm{N}^{\circ} 241$.

http://www.who.int/mediacentre/factsheets/fs241/en/index.html Accessed 2.4.2014

Widmark, C., Levál, A., Tishelman, C. \& Ahlberg, B.M. 2010. Obstetric care at the intersection of science and culture: Swedish doctors' perspectives on obstetric care of women who have undergone female genital cutting. Journal of Obstetrics \& Gynaecology, 30,6:553-558.

World Bank \& UNFPA. 2004. Female Genital Mutilation/Cutting in Somalia, World Bank \& UN Population Fund, New York, NY, USA. 
Yasin, B., Al-Tawil, N., Shabila, N. \& Al-Hadithi, T. 2013. Female genital mutilation among Iraqi Kurdish women: a cross-sectional study from Erbil city. BMC Public Health, 13:809.

Yirga, W., Kassa, N., Gebremichael, M. \& Aro, A. 2012. Female genital mutilation: prevalence, perceptions and effect on women's health in Kersa district of Ethiopia. International Journal of Women's Health 2012:4. 45-54. 


\title{
6. Article
}

\section{Female genital mutilation/cutting among women of Somali and Kurdish origin in} Finland

Koukkula, Mimmi J., Keskimäki Ilmo T., Koponen Päivikki M.S., Mölsä Mulki, Klemetti Reija M.

\begin{abstract}
Background: The tradition of female genital mutilation/cutting (FGM/C) has spread in Europe due to immigration. Although it is known to have several negative health impacts, the exact prevalence of FGM/C and its health effects in Finland are unknown. This study explores the prevalence of FGM/C, the sociodemographic characteristics associated with it, and its health effects among women of Somali and Kurdish origin in Finland.
\end{abstract}

Methods: Data were obtained from the Migrant Health and Wellbeing Study carried out in 2010-2012, which was an interview survey with respondents representing the main migrant ethnic groups in Finland. This study uses data from interviews with Somali $(\mathrm{N}=165)$ and Kurdish $(\mathrm{N}=224)$ women. The participation rate for the interview was $37 \%$ for the women of Somali and $54 \%$ of Kurdish origin.

Results: The prevalence of FGM/C was $69 \%$ among the women of Somali and $32 \%$ among the women of Kurdish origin. Having no education and older age were significantly associated with FGM/C, as was marriage amongst women of Somali origin, and practice of Islam amongst women of Kurdish origin. Reporting good self-perceived health was more common among women without FGM/C. Outpatient visits to medical doctors were less common among women of Somali origin with FGM/C, compared to women without FGM/C. One fifth of both women of Somali and Kurdish origin with FGM/C reported reproductive problems because of FGM/C.

Conclusion: FGM/C is more common among migrant women living in Finland than previously estimated, particularly among women of Kurdish origin. Actions against FGM/C are needed and the negative impacts of FGM/C need to be addressed in health services for immigrant women. 
- Keywords: FGM/C, female genital mutilation, female genital cutting, circumcision, female*, migrant women

\section{Introduction}

Female genital mutilation/cutting (FGM/C) includes all procedures that are performed for non-medical reasons involving partial or total removal of the external female genitalia, or other injury to the female genital organs. $\frac{1,2}{-}$ An estimated 125 million girls and women live with FGM/C in the world today, and three million girls are at risk of be subjected to the practice every year. Most of the girls who have been subjected to the practice live in Africa, Asia and the Middle East. Due to immigration, the tradition has spread in Europe and North America. It has been estimated that half a million girls and women in Europe have been subjected to $\mathrm{FGM} / \mathrm{C} .{ }^{-}$The risk of $\mathrm{FGM} / \mathrm{C}$ is still present after immigration to Europe. Although there is no evidence that FGM/C is practiced within the area of the European Union, the daughters of immigrants form a large group who may be subjected to FGM/C while travelling outside the EU. It is estimated that 180000 girls are at risk of FGM/C in Europe. Isman et al. ${ }^{4}$ estimated in their study that in Scandinavia there are 100000 immigrants from countries where $\mathrm{FGM} / \mathrm{C}$ is a tradition. Elgaali et al. ${ }^{5}$ showed in their quantitative study that $19 \%$ of the daughters of African immigrants in Scandinavia had been circumcised whilst living in Scandinavia. However, in most European countries, and in Finland there are no precise estimates for the prevalence and the health impacts of FGM/C among immigrant women living in the country.

Studies on FGM/C, its' health consequences and care requirements are scarce and are concentrated on African countries. ${ }^{6} \mathrm{FGM} / \mathrm{C}$ has been internationally recognized as a violation of human rights. ${ }^{7,2}$ The ancient tradition also reflects inequality between the sexes and discrimination against women. The tradition violates children's rights and individuals' right to health, security and physical sanctity.

FGM/C has several negative health impacts. $\frac{7,2,6, \underline{8}}{2}$ The degree of cutting and the circumstances under which the procedure is performed affect the incidence of negative health impacts. FGM/C can cause short-term impacts such as severe pain, bleeding and infections and long-term impacts such as painful menstruation 
and intercourse, cysts and psychosocial problems. Childbirth complications such as prolonged labour, obstruction, perineal tears and postpartum haemorrhage are common among women who have been subjected to $\mathrm{FGM} / \mathrm{C}$.

The number of migrants to Finland has been growing during the past decade. In 2012, over 220000 citizens of foreign origin were living in Finland with Russians, Estonians, Somalis, and Iraqis forming the biggest groups. ${ }^{9}$ FGM/C prevalence is known to be high among Somalis. $\stackrel{10}{ }$ However there is little information on the tradition of FGM/C among Kurdish women. In Finland the Ministry of Social Affairs and Health has published a specific action plan on the prevention of FGM/C for the years $2012-2016 . \stackrel{11}{\text { Yet }}$ there is little information on the prevalence of FGM/C among migrants In Finland, ${ }^{\frac{3}{3}}$ while the experienced health effects have not been studied. The purpose of this study is to explore the prevalence of FGM/C and its perceived health effects. We also study whether FGM/C is associated with socio-demographic characteristics, selfperceived health, and outpatient visits to a medical doctor among women of Somali and Kurdish origin in Finland.

\section{Methods}

In Finland, the National Institute for Health and Welfare (THL) collected data on health, well-being, use of services, and living conditions of working-aged immigrants of Russian, Somali and Kurdish origin in 20102012. The Migrant Health and Wellbeing Study (Maamu) has been described in more detail elsewhere. ${ }^{12}$ The FGM/C status was asked in personal interviews with women of Somali and Kurdish origin. The Maamu study is so far the most representative and largest data set in Finland that allows an estimate of the prevalence of FGM/C and the socio-demographic factors associated with it among migrants.

Data were collected in six municipalities with the highest proportions of migrants, three in the metropolitan area (Helsinki, Espoo, Vantaa) and three in other parts of the country (Turku, Tampere, Vaasa). These municipalities covered $93 \%$ of Somali and $67 \%$ of Kurdish origin migrants who met the inclusion criteria in Finland in 2008. A sample of 1000 persons from each ethnic group was randomly selected from the 
National Population Registry, including information regarding the country of birth and mother tongue. A person with Somalia as a country of birth was defined as being of a Somali origin. A person with Iraq or Iran as a country of birth and Kurdish Soran as the mother tongue was defined as being of Kurdish origin. The invitees were aged between 18-64 years and had lived in Finland for at least one year. The sampling method was stratified random sampling by municipality and ethnic group. The size of the migrant population defined the sample size in each of the six municipalities.

Bilingual interviewers and research nurses implemented the interviews to ensure data quality. The mother tongue of the interviewers had to be Somali or Kurdish Soran. The interviewers had two weeks training before the study. Since the theme is gender-sensitive the questions concerning FGM/C were only asked by a female interviewer; therefore these sensitive questions were not asked from all the women who took part in the interviews. $85 \%$ of Somali and $97 \%$ of Kurdish female participants responded to these questions.

The Coordinating Ethical Committee of the Helsinki and Uusimaa Hospital Region gave ethical approval for the study (19.1.2010 325/13/00/2009). The participants gave their written informed consent for the health interview.

This study uses data from the interviews of 165 women of Somali origin and 224 women of Kurdish origin. The participation rate varied; $54 \%$ for Kurdish and $37 \%$ for Somali. ${ }^{12}$ Interview questions concerning the following themes were selected for this study:

A. Socio-demographic background: 1. Age. 2. Religion: None, Orthodox, Lutheran, Muslim, Jewish, Something else. 3. Marital status: Married, Civil union, Cohabitation, Divorced, Widower, Unmarried. 4. Education: No education, Primary, Secondary or higher.

B. Self-perceived health: Good, Rather good, Moderate, Rather Poor, Poor.

C. Reproductive health: 1. FGM/C: Yes, No. 2. Problems during pregnancy or delivery due to FGM/C: Yes, No. Problems including: Not willing to give birth ever again because of difficult delivery: Yes, No. Infections 
due to FGM/C: Yes, No. Pain due to FGM/C: Yes, No. Difficulties in marital life due to FGM/C: Yes, No. Other health problems related to FGM/C: Yes, No. 4. Miscarriages (ever had at least one): Yes, No.

D. Utilization of health care services: 1 . Has made an outpatient visit to a medical doctor (at least once) because of illness or pregnancy or birth during the past 12 months: Yes, No.

E. Satisfaction with own health: Very satisfied or satisfied, Not satisfied or unsatisfied, Unsatisfied, Very unsatisfied.

Data analyses were conducted using Stata version 13.1 (STATA Corporation, College Station, TX). Different sampling probabilities and nonresponse were controlled using inverse probability weights based on age group, sex, ethnic group, study location and civil status (data from the Population Register obtained for the total sample in the Maamu study). Descriptive statistics and frequency distributions were used to describe the data, while cross-tabulations were used to explore the associations between the socio-demographic factors, self-perceived health, health care utilization, and FGM/C. The models were adjusted for age. The statistical significance of the differences was tested using Pearson's chi-square (x2), Fisher's test or the Adjusted Wald test; the limit for statistical significance was set at $5 \%(p<0.05)$.

Binary logistic regression analyses were used to describe the associations as crude odds ratios (OR) with 95\% confidence interval $(\mathrm{CI})$. The dependent variable in the logistic regression model was FGM/C (Yes=1, No=0). The statistically significant explanatory variables from the univariate analysis were entered into multivariate logistic regression analysis to control for possible confounding effects.

\section{Results}

The total number of women who answered the question about FGM/C was 389; 165 of Somali origin and 224 of Kurdish origin (Table 1). The mean age among women of Somali origin was 34.3 years (SD 11.9), ranging from 18 to 63 and among women of Kurdish origin 35.8 (SD10.0), ranging from 18 to 62 . In the 
Somali origin group all but one person were Muslims and in the Kurdish origin group three quarters of respondents were Muslims. Two-thirds of women in both groups were married or in a civil union or in a registered partnership. One-third of Somali and one-fifth of Kurdish origin women had no school education.

In the Somali origin group, four-fifths defined their self-perceived health as good, whereas in the Kurdish origin group, two-thirds of respondents reported the same (Table 1). Three-fifths of the Somali origin women, and three-quarters of the Kurdish origin women had made an outpatient visit to see a medical doctor at least once during the last 12 months. Nearly all of the Somali origin women and two-thirds of Kurdish origin women were satisfied with their health. When age was adjusted, the prevalence of FGM/C was $69 \%$ among women of Somali origin and $32 \%$ among women of Kurdish origin (Table 2). Nearly a fifth of the women with FGM/C reported problems during pregnancy or delivery because of FGM/C. Only a few reported other health problems due to FGM/C.

Table 1 and 2

Marriage or civil union was significantly more common among Somali origin women with FGM/C than those without FGM/C (Table 3). Women of Somali origin with FGM/C significantly more often had no school education compared to those without FGM/C. Kurdish origin women with FGM/C were more often Muslims than women without FGM/C. Having no school education was significantly more common among Kurdish origin women with $\mathrm{FGM} / \mathrm{C}$ than those without $\mathrm{FGM} / \mathrm{C}$.

Good self-perceived health was reported more often by Somali origin women without FGM/C than Somali women with FGM/C (Table 3). Outpatient visits to a medical doctor were significantly more common among women of Somali origin without FGM/C than Somali women with FGM/C. Over $90 \%$ of Somali origin women were satisfied with their health - FGM/C status made no difference. The differences in good perceived health and utilization of health services were coaxial among women of Kurdish origin though the 
differences were not statistically significant. Women of Kurdish origin with FGM/C were more often very satisfied or satisfied with their health than Kurdish women without FGM/C.

Table 3

Older age, being married or in a civil union and having no school education were significantly associated with FGM/C within the Somali origin group (Table 4). The strongest of all predictors of FGM/C among women of Kurdish origin was education; after adjustment for other variables the odds for FGM/C were 10fold among women with no education compared with women with secondary or higher education. Women with primary education had 3.5-fold odds for FGM/C when compared with higher educated women.

Somali origin women with $\mathrm{FGM} / \mathrm{C}$ had less often made outpatient visits to a medical doctor compared to women without FGM/C when adjusted for age, marital status and education (Table 4). The adjusted results showed that women of Somali origin with FGM/C perceived their health to be good much more seldom than women without FGM/C. The FGM/C-status of women of Kurdish origin was not statistically significantly associated with health care utilization. When adjusted for age, marital status, education and religion the odds for being satisfied with health was 1.8-fold for women of Kurdish origin with FGM/C when compared to Kurdish women without FGM/C.

Table 4

\section{Discussion}

This study showed that the prevalence of FGM/C among ethnic minority women living in Finland is higher than has previously been estimated, particularly among women of Kurdish origin. Older age and having no education were strongly associated with $\mathrm{FGM} / \mathrm{C}$ in both Somali and Kurdish origin groups. Also, among women of Somali origin, being married was strongly associated with $\mathrm{FGM} / \mathrm{C}$. Although $\mathrm{FGM} / \mathrm{C}$ is not a religious tradition among women of Kurdish origin, being Muslim was also associated with FGM/C. The 
association of religion could not be studied among women of Somali origin, since nearly all of the participants were Muslims. Reporting good self-perceived health was more common among women without FGM/C. Outpatient visits to a medical doctor were more common among women without FGM/C. The results show that one fifth of the women with $\mathrm{FGM} / \mathrm{C}$ had had problems during pregnancy or labour due to $\mathrm{FGM} / \mathrm{C}$.

The strength of this study is that it is based on a random population sample. A population-based survey is a good tool for estimating the prevalence of FGM/C and it also enables the study of other outcomes as well and their associations with FGM/C. It is known that it is challenging to study migrants as a target population because migrants do not tend to take part in demographic surveys, with language and cultural reasons forestalling their participation. $\frac{13}{3}$ So the moderate response rate ( $37 \%$ of Somali origin women and $54 \%$ of Kurdish origin women) can be considered reasonable for a migrant survey. Interviewers in the data collection phase were of the same origin as the participants, which helped to confirm the communication with participants in their own mother tongue, to build trust, and to show understanding towards the respondents' cultures.

The subject of $F G M / C$ is very sensitive. While the FGM/C-status was not examined, only asked about, there is a chance of reporting and recall bias, as probably not all those interviewed have been able or willing to tell about their FGM/C situation in the interview. In 26 Somali and 6 Kurdish origin cases there was a male interviewer and the question about $\mathrm{FGM} / \mathrm{C}$ was not asked or the participants refused to answer the question about FGM/C. This may have led to an underestimation of the prevalence of FGM/C. Respondents may know that FGM/C is illegal in Finland, which might have meant that social acceptability bias led to underreporting of FGM/C. It is also possible that many of the women with FGM/C may not have connected any experienced symptoms and discomforts with FGM/C. Due to cultural attitudes and Islam, one has to be resilient about what happened in the past, especially if one's parents were responsible; thus, women with FGM/C often do not complain about the discomforts they have and the negative health consequences can 
be underreported and health can be perceived in a positive perspective. A selection bias may also be present as the most active people tend to participate most actively in surveys.

In this study having no school education was strongly associated with $\mathrm{FGM} / \mathrm{C}$, which is in line with previous studies. $\stackrel{14,15}{ }$ Refaat et al. $\stackrel{14}{~}$ showed that urban and educated women's daughters are less likely to undergo

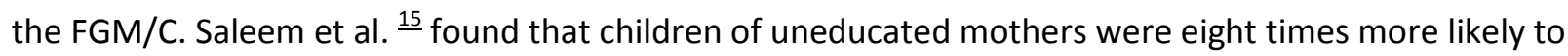
have had FGM/C compared with children of mothers with over nine years of education. Also the education of the girl's father and the employment status of the girl's mother have been shown to be significant factors associated with FGM/C. ${ }^{16} \mathrm{FGM} / \mathrm{C}$ is usually performed in childhood so the prevailing sociodemographic situation does not directly tell about the risk of being circumcised. Still, the results indicate that women with low education status need more information on $\mathrm{FGM} / \mathrm{C}$, as their daughters may be at higher risk of FGM/C. Mostly it is mothers who arrange the mutilation of their daughters. Most noneducated older women with FGM/C in our study are likely to have migrated to Finland after school age and they may be more fastened to their own culture.

Results concerning marital status were in line with Saleem's et al. ${ }^{15}$ study in showing that FGM/C is more common among married than unmarried women. FGM/C was more common in older age groups, which shows the decline in the practice among younger generations. Preventive work both in Finland and in the countries of origin are also likely to have had some effect.

Utilization of outpatient medical care was more common among women without FGM/C in this study. Parallel results were seen in the study of Norman et al. $\stackrel{17}{ }$ as the women with FGM/C reported many barriers to health service utilization. In the study in the United Kingdom, women with FGM/C lacked knowledge about FGM/C, while the poor communication skills of the health providers led to poor management of childbirth and women feeling different or abnormal. These reasons can lead to underutilization of health care services. A confounding factor may be the length of the stay in the new home country. Migrants tend to utilize health care services less than the general population and the custom of using western health care services can be learned gradually. $\underline{\underline{18}}$ 
In this study, the association of poor self-perceived health and FGM/C was not as strong as for example in Andros' et al.'s $\underline{6}$ study. FGM/C has negative impacts on health and it can cause problems during pregnancy and delivery. These impacts need to be addressed in health services for immigrant women. Moreover, the association between FGM/C and the use of health care services was not definitive. To confirm the results, further studies are needed with larger data sets. The use of birth register data, for instance, would also make it possible to adjust for different background factors.

The present study shows that education, marital status and older age are the main socio-demographic factors associated with $\mathrm{FGM} / \mathrm{C}$ in Finland. FGM/C is more common among migrant women living in Finland than was previously estimated, especially among women of Kurdish origin, with likely increased negative health impacts. Actions against FGM/C are needed, not only in the areas where it is practiced but also in Europe, -as it violates human rights and has negative health impacts. The results indicate that women with low education status need more information on $\mathrm{FGM} / \mathrm{C}$, as their daughters may be at higher risk of being cut. Professionals in health care, education and migration should be trained to address the tradition, to focus on prevention, but also to give their support to women living with $\mathrm{FGM} / \mathrm{C}$ or who are at risk of being subjected to the practice. Campaigns against FGM/C need to be targeted towards immigrant communities in Europe, as these also may have an impact in their country of origin.

\section{Acknowledgements}

We would like to acknowledge the participants and the field-work personnel of the Maamu Study, as well as all experts who were involved in the planning and implementation of the study.

MK was funded by the Finnish Midwife Union with a stipend.

\section{Conflicts of interest}

IK is asked to advise the Finnish Ministry of Health and Social Affairs from time to time on matters relating to health policy and services; regardless of the findings of this study, the outputs of this research would form part of that advice. 
Other authors have no conflict of interest. The authors are not affiliated with the pharmaceutical industry nor are paid to produce any sort of pre-agreed results.

\section{Key-points}

- FGM/C is more common among migrant women living in Finland than previously estimated, especially among women of Kurdish origin.

- $\quad$ FGM/C needs attention also in Europe -as it violates human rights and has negative health impacts.

- Professionals in health care, education and migration should be trained to address the tradition, to focus on prevention, and to give their support to women living with FGM/C or who are at risk of being subjected to the practice. 


\section{REFERENCES}

1. WHO. Female genital mutilation. Fact sheet $\mathrm{N}^{\circ} 241$. http://www.who.int/mediacentre/factsheets/fs241/en/index.html Accessed (25.4.2015)

2. UNICEF. Female Genital Mutilation/Cutting: A statistical overview and exploration of the dynamics of change. New York, United Nations Children's Fund, 2013.

3. EIGE. European Institute for Gender Equality. Female genital mutilation in the European Union and Croatia. Report. European Union, 2013.

4. Isman E, Ekéus C, Berggren V. Perceptions and experiences of female genital mutilation after immigration to Sweden: An explorative study. Sexual \& Reproductive Healthcare 2013; 4: 93-98.

5. Elgaali M, Strevens H, Mårdh PA. Female genital mutilation -- an exported medical hazard. The European Journal of Contraception and Reproductive Health Care 2005; 10(2): 93-7.

6. Andro A, Cambois E, Lesclingand M. Long-term consequences of Female Genital Mutilation in a European context: self perceived health of FGM women compared to non-FGM women. Social Science \& Medicine 2014; Apr;106: 177-84.

7. WHO. An update on WHO's work on female genital mutilation (FGM). Progress report, 2011.

8. Balogun O, Hirayama F, Wariki W, Koyanagi A, Mori R. Interventions for improving outcomes for pregnant women who have experienced genital cutting (Review). The Cochrane Library 2013, Issue 2 .

9. Official Statistics of Finland (OSF): Official Statistics of Finland [e-publication]. Helsinki: Advisory Board of OSF http://www.stat.fi/meta/svt/index en.html Accessed (3.4.2015)

10. World Bank \& UNFPA. Female Genital Mutilation/Cutting in Somalia. World Bank \& UN Population Fund, New York, NY, USA, 2004.

11. Ministry of Social Affairs and Health. Action Plan for the prevention of circumcision of girls and women 2012-2016 (FGM). Publications of the Ministry of Social Affairs and Health 2012:14. Helsinki 2012. 43 p.

12. Castaneda A, Rask S, Koponen P, Mölsä M, Koskinen S. (ed.) 2012. Migrant health and wellbeing. A study on persons of Russian, Somali and Kurdish origin in Finland. National Institute for Health and Welfare (THL). Report 61/2012. Helsinki 2012. (Report in Finnish with English summary)

13. Rechel B, Mladovsky P, Deville W. Monitoring migrant health in Europe: A narrative review of data collection practices. Health Policy 2012;105(1):10-16.

14. Refaat L, Farag A, Ramadan I. Socio-demographic characteristics of female genital mutilation and its relation to sexual function. AAMJ 2009; Vol.7, no.2.

15. Saleem R, Othman N, Fattah F, Hazim L, Adnan B. Female Genital Mutilation in Iraqi Kurdistan: Description and Associated Factors. Women \& Health 2013; (vol)53:6: 537-551. 
16. Yasin B, Al-Tawil N, Shabila N, Al-Hadithi T. Female genital mutilation among Iraqi Kurdish women: a cross-sectional study from Erbil city. BMC Public Health 2013;13:809.

17. Norman K, Hemmings J, Hussein E, Otoo-Oyortey N. FGM is always with us. Experiences, perceptions and beliefs of women affected by female genital mutilation in London. Results from $A$ PEER study. Options Consultancy Services and Foundation for Women's Health, Research and Development, 2009; London.

18. Rask S, Castaneda A, Koponen P, Sainio P, Stenholm S, Suvisaari J, Juntunen T, Halla T, Härkänen T, Koskinen $\mathrm{S}$. The association between mental health symptoms and mobility limitation among Russian, Somali and Kurdish migrants: a population based study. BMC Public Health 2015, 15:275. 
Table 1. Background characteristics, self-perceived health, outpatient visits to doctor, and satisfaction with health of Somali and Kurdish origin women, weighted (IPW) \% and mean.

\begin{tabular}{|c|c|c|c|c|}
\hline & $\begin{array}{l}\text { Somali ori } \\
\text { women } \\
\mathrm{N}=165\end{array}$ & & $\begin{array}{l}\text { Kurdish o } \\
\text { women } \\
\mathrm{N}=224\end{array}$ & \\
\hline Age & $\overline{\mathrm{N}}$ & $\%$ & $\bar{N}$ & $\%$ \\
\hline $18-29$ & 64 & 40.5 & 65 & 29.9 \\
\hline $30-44$ & 60 & 37.7 & 108 & 48.1 \\
\hline $45-64$ & 41 & 21.8 & 51 & 22.0 \\
\hline $\begin{array}{l}\text { Mean age } \\
\text { SD } \\
\text { CI }\end{array}$ & $\begin{array}{l}34.3 \\
11.9 \\
32.5-36.1\end{array}$ & & $\begin{array}{l}35.8 \\
10.0 \\
34.6-37.0\end{array}$ & \\
\hline \multicolumn{5}{|l|}{ Religion } \\
\hline Muslim & 164 & 99.4 & 168 & 74.5 \\
\hline Other/None & 1 & 0.6 & 56 & 25.6 \\
\hline \multicolumn{5}{|l|}{ Marital Status } \\
\hline Married/Civil union & 110 & 66.0 & 161 & 68.5 \\
\hline Unmarried/Divorced/Widow & 53 & 34.0 & 63 & 31.5 \\
\hline \multicolumn{5}{|l|}{ Education } \\
\hline No education & 63 & 32.6 & 42 & 17.7 \\
\hline Primary & 76 & 49.7 & 87 & 39.0 \\
\hline Secondary/ Higher & 24 & 17.7 & 94 & 43.3 \\
\hline Miscarriages (ever had at least one) & 52 & 30.1 & 58 & 24.9 \\
\hline \multicolumn{5}{|l|}{ Self-perceived health } \\
\hline Good or rather good & 135 & 82.3 & 137 & 62.7 \\
\hline Poor or moderate & 29 & 17.7 & 87 & 37.3 \\
\hline $\begin{array}{l}\text { Outpatient visit to doctor in } 12 \\
\text { months }\end{array}$ & 97 & 59.5 & 168 & 74.7 \\
\hline \multicolumn{5}{|l|}{ Satisfaction with own health } \\
\hline $\begin{array}{l}\text { Satisfied } \\
\end{array}$ & 151 & 93.1 & 137 & 62.1 \\
\hline Unsatisfied & 10 & 6.9 & 87 & 37.9 \\
\hline
\end{tabular}


Table 2. Prevalence and health problems related to FGM/C among Somali and Kurdish origin women, weighted (IPW) \% and mean.

\begin{tabular}{|l|l|l|l|l|}
\hline & \multicolumn{2}{|l|}{$\begin{array}{l}\text { Somali origin } \\
\text { women N=165 }\end{array}$} & \multicolumn{2}{l|}{$\begin{array}{l}\text { Kurdish origin } \\
\text { women N=224 }\end{array}$} \\
\hline & N & \% & N & \% \\
\hline FGM/C (a) & $\mathbf{1 1 5}$ & $\mathbf{6 9 . 0}$ & $\mathbf{7 1}$ & $\mathbf{3 2 . 1}$ \\
\hline $\begin{array}{l}\text { Problems during pregnancy because of } \\
\text { FGM/C }\end{array}$ & 18 & 17.9 & 14 & 18.3 \\
\hline Difficult delivery & & & & \\
\hline Infections & 2 & & 5 & \\
\hline Pain & 3 & & 4 & \\
\hline Difficulties in marital life & 10 & & 5 & \\
\hline Other health problems because of FGM & 2 & & 14 & \\
\hline
\end{tabular}

a) Age adjusted. 
Table 3. Background characteristics, self-perceived health, outpatient visits to doctor and satisfaction with health of Kurdish and Somali origin women with and without FGM/C, weighted (IPW) \%.

\begin{tabular}{|c|c|c|c|c|c|c|}
\hline & \multicolumn{3}{|c|}{$\begin{array}{l}\text { Somali origin women } \\
N=165\end{array}$} & \multicolumn{3}{|c|}{$\begin{array}{l}\text { Kurdish origin women } \\
\mathrm{N}=\mathbf{2 2 4}\end{array}$} \\
\hline & $\mathrm{FGM} / \mathrm{C} \%$ & $\begin{array}{c}\text { No } \\
\text { FGM/C\% }\end{array}$ & $\mathrm{p}(\mathrm{a}$ & $\mathrm{FGM} / \mathrm{C} \%$ & $\begin{array}{c}\text { No } \\
\text { FGM/C\% }\end{array}$ & $\mathrm{p}(\mathrm{a}$ \\
\hline Muslim & 99.1(b) & 100(b) & 0.476 & 83.8 & 69.6 & 0.006 \\
\hline Married/In civil union & 74.4 & 50.1 & 0.002 & 74.5 & 65.7 & 0.130 \\
\hline No education & 35.1 & 27.6 & 0.029 & 33.9 & 9.3 & $<0.001$ \\
\hline Miscarriages & 31.4 & 26.7 & 0.539 & 23.1 & 25.9 & 0.559 \\
\hline Good self-perceived health & 49.4 & 68.9 & 0.005 & 39.5 & 41.3 & 0.749 \\
\hline Poor self-perceived health & 3.6 & 12.7 & 0.080 & 11.4 & 9.5 & 0.571 \\
\hline $\begin{array}{l}\text { Outpatient visit to doctor in } 12 \\
\text { months }\end{array}$ & 53.3 & 72.0 & 0.023 & 71.7 & 76.1 & 0.388 \\
\hline Very satisfied/Satisfied with health & 94.2 & 90.3 & 0.344 & 69.5 & 58.2 & 0.044 \\
\hline
\end{tabular}

a)P-value in Chi-square test.

b)Age not adjusted. 
Table 4. Raw and adjusted* Odds Ratios for socio-demographic factors, outpatient visits to doctor, selfperceived health and satisfaction with health by FGM/C among Somali and Kurdish origin women.

* Adjusted for age, marital status, education and religion (Kurdish origin).

\begin{tabular}{|c|c|c|c|c|}
\hline \multirow[b]{2}{*}{ Age } & \multicolumn{2}{|c|}{$\begin{array}{l}\text { Somali origin women } \\
N=165\end{array}$} & \multicolumn{2}{|c|}{$\begin{array}{l}\text { Kurdish origin women } \\
\mathrm{N}=224\end{array}$} \\
\hline & OR $(95 \% \mathrm{CI})$ & $\begin{array}{l}\text { Adjusted OR } \\
(95 \% \mathrm{CI})\end{array}$ & OR $(95 \% \mathrm{CI})$ & $\begin{array}{l}\text { Adjusted OR } \\
(95 \% \mathrm{CI})\end{array}$ \\
\hline $18-29$ & 1.00 & 1.00 & 1.00 & 1.00 \\
\hline $30-44$ & $3.13(1.51-6.48)$ & $2.71(1.17-6.30)$ & $2.02(1.16-3.51)$ & $1.78(0.97-3.26)$ \\
\hline $45-64$ & $5.21(2.09-13.0)$ & $4.46(1.68-11.84)$ & $1.35(0.68-2.68)$ & $0.94(0.44-2.01)$ \\
\hline \multicolumn{5}{|l|}{ Marital Status } \\
\hline Married/Civil union & $3.38(1.73-6.59)$ & $2.64(1.23-5.68)$ & $1.31(0.98-2.94)$ & $1.31(0.72-2.39)$ \\
\hline Unmarried/Divorced/Widowed & 1.00 & 1.00 & 1.00 & 1.00 \\
\hline \multicolumn{5}{|l|}{ Education } \\
\hline No education & $3.73(1.49-9.36)$ & $3.03(1.09-8.45)$ & $11.04(5.57-21.89)$ & $9.88(4.76-20.47)$ \\
\hline Primary & $2.91(1.22-6.94)$ & $2.31(0.99-5.39)$ & $3.68(2.05-6.61)$ & $3.52(1.96-6.34)$ \\
\hline Secondary/ Higher & 1.00 & 1.00 & 1.00 & 1.00 \\
\hline \multicolumn{5}{|l|}{ Religion } \\
\hline Muslim & & & $2.02(1.12-3.63)$ & $1.53(0.76-3.07)$ \\
\hline Other & & & 1.00 & 1.00 \\
\hline $\begin{array}{l}\text { Outpatient visit to doctor in } \\
12 \text { months }\end{array}$ & OR $(95 \% \mathrm{CI})$ & $\begin{array}{l}\text { Adjusted OR } \\
(95 \% \mathrm{CI})\end{array}$ & OR $(95 \% \mathrm{CI})$ & $\begin{array}{l}\text { Adjusted OR } \\
(95 \% \mathrm{CI})\end{array}$ \\
\hline No FGM/C & 1.00 & 1.00 & 1.00 & 1.00 \\
\hline FGM/C & $0.26(0.13-0.53)$ & $0.36(0.16-0.80)$ & $0.92(0.54-1.58)$ & $0.61(0.34-1.10)$ \\
\hline \multicolumn{5}{|l|}{ Self-perceived health good } \\
\hline No FGM/C & 1.00 & 1.00 & 1.00 & 1.00 \\
\hline FGM/C & $0.54(0.22-1.28)$ & $0.36(0.17-0.77)$ & $0.80(0.50-1.28)$ & $1.34(0.75-2.38)$ \\
\hline \multicolumn{5}{|l|}{ Satisfied with health } \\
\hline No FGM/C & 1.00 & 1.00 & 1.00 & 1.00 \\
\hline FGM/C & $1.39(0.45-4.34)$ & $1.88(0.50-7.02)$ & $1.42(0.88-2.30)$ & $1.81(1.03-3.18)$ \\
\hline
\end{tabular}

